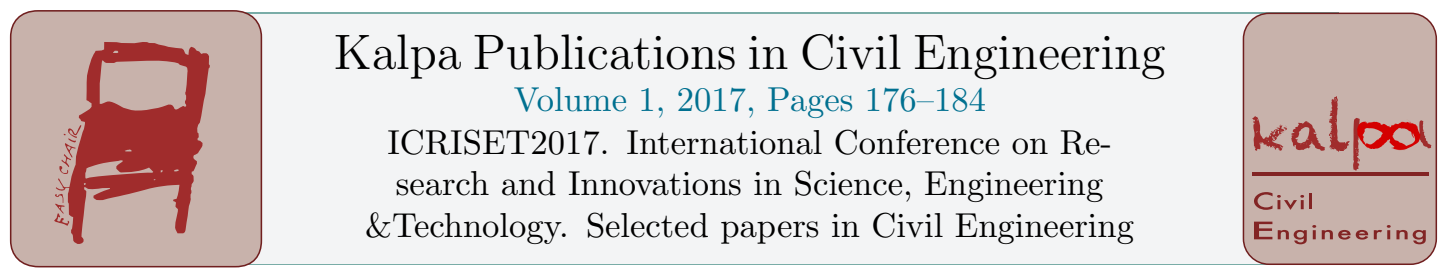

\title{
Evaluating the Efficacy of Warm Mix Asphalt
}

\author{
Supriya Mahida ${ }^{1}$ and Chandravadan B. Mishra ${ }^{2}$ \\ ${ }^{1}$ PG Student, Civil Engineering Department, Birla Vishvakarma Mahavidyalaya, Vallabh \\ Vidyanagar, Anand, Gujarat, India \\ ${ }^{2}$ Associate Prof. Civil Engineering Department, Birla Vishvakarma Mahavidyalaya, Vallabh \\ Vidyanagar, Anand, Gujarat, India. \\ supriyamahida@gmail.com, cbmishra@bvmengineering.ac.in
}

\begin{abstract}
This paper concentrates on the research center examination of the attributes and performance of warm mix asphalt containing compound added substance. Viscosity grade 30 bitumen was utilized for this study and the WMA added substances utilized as a part of this review were Evotherm and Sasobit. Consistency tests demonstrated the utilized warm mix additives are within permissible limit. Information got from indirect tensile test, tensile strength ratio test, static and dynamic creep test demonstrated that the blends containing warm mix asphalt added substances performed better in contrast with hot mix asphalt. Warm mix asphalt samples indicated lesser aggregate lasting strain gathering in contrast with HMA specimens, Sasobit altered warm blend black-top specimens demonstrated the minimum deformation.
\end{abstract}

Keywords - Warm Mix Asphalt; Marshall Stability; Moisture Susceptibility; Creep

\section{Introduction}

The hot-mix asphalt (HMA) industry looks for rising innovations that lessen environmental effect amid creation of bituminous clearing materials. Warm mix asphalt is generic term for an assortment of advances that permit the makers of hot mix asphalt to bring down the temperatures at which the material is mixed and set out and about in India (Hurley and Prowell, 2004 and Anderson et al. 2008). The idea of WMA was presented in late 1990's in Europe. After that various WMA forms have been created in Europe and the United States (Mallick et al. 2007, Prowell et al. 2007).

In spite of the fact that there is no standard measure of workability of black-top clearing mixtures, a few scientists have created exact tests to gauge workability of clearing mixtures for relative purposes. A few scientists have utilized workability tests as a part of an endeavor to decide which WMA innovations give enhanced workability, what measurement of WMA added substance gives ideal workability and compaction (Bennert et al. (2010). The blending and compaction temperatures are normally decided on the premise of the temperature-consistency diagram. The thickness is considered as a viable marker for the estimation of binder workability (Airey et al., 2008). Bring 
down blending temperatures can bring about poor bitumen coating and in this way make the bituminous blend susceptible to dampness harm (L Mo et al., 2012). Diminished compaction temperatures additionally prompt to lacking blend compaction which can bring about untimely pavement failure. Literature study uncovers that consistency decrease is by all account not the only system that supports lessened production temperatures for WMAs ( Hanz et al. (2010), yet the lubricity impacts of these warm mix added substances into the fastener were vital to advance mixture workability and compactability at lower temperatures (Fabricio and Randy, 2008).

This paper expects to research the performance of warm mix asphalt containing two main categories of WMA technologies added substances at lowered temperature, which can lead down to a reduction in design asphalt content if incorporated in the blend configuration process.

\section{Research Rubric}

\subsection{Aggregate Test}

For the bituminous pavement, aggregate with specific characteristics is used for road laying. The aggregate is chosen on the basis of its strength, porosity and moisture absorption capacity. The aggregate properties are shown in Table 1.

Table 1: Summary of Aggregate Test

\begin{tabular}{|c|c|c|c|c|}
\hline $\begin{array}{l}\text { Sr. } \\
\text { No. }\end{array}$ & Property & Test & $\begin{array}{l}\text { Recommended } \\
\text { Value as per } \\
\text { MORTH 500-8 }\end{array}$ & Test Result \\
\hline \multirow{3}{*}{1} & \multirow{3}{*}{$\begin{array}{l}\text { Cleanliness (dust) } \\
\text { IS:2386 (Part-1)-1963 }\end{array}$} & \multirow{3}{*}{ Grain size analysis } & \multirow{3}{*}{$\begin{array}{c}\text { Max } 5 \% \\
\text { passing } 0.075 \text { IS- } \\
\text { Sieve }\end{array}$} & $\begin{array}{c}\text { Pas.30.- } \\
\text { Ret.24mm- } \\
0.34 \%\end{array}$ \\
\hline & & & & $\begin{array}{c}\text { Pas.24-Ret.14 } \\
\text { mm- } \\
0.46 \% \\
\end{array}$ \\
\hline & & & & $\begin{array}{c}\text { Pas. } 14 \text {-Ret. } 6 \\
\text { mm- } \\
0.81 \% \\
\end{array}$ \\
\hline 2 & $\begin{array}{l}\text { Particle shape, IS: 2386(Part-1)- } \\
1963\end{array}$ & $\begin{array}{l}\text { Flakiness \& Elongation } \\
\text { Indices (Combined) }\end{array}$ & $35 \%$ Max & $27 \%$ \\
\hline 3 & Strength , IS:2386 (Part-4)-1963 & $\begin{array}{l}\text { Aggregate Impact } \\
\text { Value(AIV) }\end{array}$ & $27 \%$ Max & $12 \%$ \\
\hline \multirow{3}{*}{4} & \multirow{3}{*}{ Durability, IS:2386 (Part-5)-1963 } & \multicolumn{3}{|c|}{ Soundness } \\
\hline & & Magnesium Sulphate & Max $18 \%$ & $0.54 \%$ \\
\hline & & Sodium sulphate & Max $12 \%$ & $0.28 \%$ \\
\hline 5 & Stripping , IS:6241 & $\begin{array}{c}\text { Coating and Stripping } \\
\text { Bitumen Aggregate } \\
\text { Mixtures }\end{array}$ & $\begin{array}{l}\text { Min. Retained } \\
\text { Coating } 95 \%\end{array}$ & $94 \%$ \\
\hline 6 & $\begin{array}{l}\text { Water absorption value, IS:2386 } \\
\text { (Part-3)-1963 }\end{array}$ & $\begin{array}{l}\text { Water absorption } \\
\text { value }\end{array}$ & $2 \% \operatorname{Max}$ & $1.2 \%$ \\
\hline
\end{tabular}

Representative samples of each aggregate were obtained from producer stockpiles, Sayla quarry, Gujarat for the dense bituminous macadam (DBM) blend. An aggregate blend was determined to meet Job-Mix Formula (JMF) gradation requirements, designed for $26.5 \mathrm{~mm}$ nominal size aggregate gradation as per Indian Specifications as given in Table 2.

Table 2: Aggregate Gradation for DBM Grade II (MoRTH-500-10)

\begin{tabular}{|c|c|c|}
\hline \multirow{2}{*}{ IS Sieve Size (mm) } & $\begin{array}{c}\text { Recommended Range (MoRTH- } \\
500-10)\end{array}$ & $\begin{array}{c}\text { Grading Adopted (\% } \\
\text { Passing) }\end{array}$ \\
\cline { 2 - 3 } & \multicolumn{2}{|c|}{ Total \% by wt. of aggregate passing } \\
\hline
\end{tabular}




\begin{tabular}{|c|c|c|}
\hline 37.50 & 100 & 100 \\
\hline 26.50 & $90-100$ & 95 \\
\hline 19.00 & $71-95$ & 83 \\
\hline 13.20 & $56-80$ & 68 \\
\hline 4.75 & $38-54$ & 46 \\
\hline 2.36 & $28-42$ & 35 \\
\hline 0.300 & $7-21$ & 14 \\
\hline 0.075 & $2-8$ & 5 \\
\hline
\end{tabular}

\subsection{Bitumen Test}

VG-30 (Viscosity Grade) bitumen grade is chosen for the review. Two warm blend added substances specifically Sasobit and Evotherm were utilized to get ready warm mix binder. Every added substance was blended in required measurements by weight of the bitumen. To set up a warm blend cover, the binder was heated up to a temperature of $140-150^{\circ} \mathrm{C}$ and required measurements of added substance was included and blended for 20 minute with high shear blender. Samples of Evotherm is obtained from MeadWestvaco and Sasobit from Sasol Company. The required dosages for Evotherm is $0.2 \%$ and for Sasobit is $1-3 \%$ as per the product guidelines of the company. The different percent dosages, $0.2 \%, 0.4 \%$ and $0.6 \%$ for Evotherm and $1 \%, 2 \%$ and $3 \%$ for Sasobit with VG 30 binder was taken under as pilot study and to find the most suitable dosage from economy and durability point of view. The samples were given free of cost. The physical properties obtained are shown in Table 3 .

Table 3: Summary of Test Results of VG 30 Grade Bitumen with and without Warm mix additives

\begin{tabular}{|c|c|c|c|c|c|c|c|c|c|}
\hline $\begin{array}{l}\text { Characteristics } \\
\text { of tests: }\end{array}$ & $\begin{array}{l}\text { VG } \\
30\end{array}$ & $\begin{array}{l}\text { VG } 30 \\
+ \\
0.2 \% \\
\text { E }\end{array}$ & $\begin{array}{c}\text { VG } 30 \\
+ \\
0.4 \% \\
\text { E } \\
\end{array}$ & $\begin{array}{l}\text { VG } 30 \\
+ \\
0.6 \% \\
\text { E } \\
\end{array}$ & $\begin{array}{c}\text { VG } 30 \\
+ \\
1 \% \\
\mathrm{~S} \\
\end{array}$ & $\begin{array}{l}\text { VG } 30 \\
+ \\
2 \% \\
\mathrm{~S} \\
\end{array}$ & $\begin{array}{c}\text { VG } 30 \\
+ \\
3 \% \\
\text { S } \\
\end{array}$ & $\begin{array}{l}\text { Min. } \\
\text { Limit }\end{array}$ & Code \\
\hline $\begin{array}{l}\text { Penetration } \\
(\mathrm{mm})\end{array}$ & 65 & 57.8 & 57.2 & 56.1 & 45.2 & 46.4 & 47.6 & Min 45 & IS 1203 \\
\hline $\begin{array}{l}\text { Softening point } \\
\left(\mathrm{C}^{\circ}\right)\end{array}$ & 57 & 48 & 49 & 51 & 70 & 68 & 64 & Min 47 & IS 1205 \\
\hline Ductility $(\mathrm{cm})$ & $70+$ & $70+$ & $70+$ & $70+$ & $70+$ & $70+$ & $70+$ & Min 40 & IS 1208 \\
\hline $\begin{array}{l}\text { Absolute } \\
\text { Viscosity at } 60 \\
\left(\mathrm{C}^{\circ}\right) \text {, Poise }\end{array}$ & 2454 & 2478 & 2492 & 2515 & - & - & - & $\begin{array}{l}\text { Min } \\
2400\end{array}$ & $\begin{array}{l}\text { IS } 1206 \text { (part } \\
\text { 2) }\end{array}$ \\
\hline $\begin{array}{l}\text { Kinematic } \\
\text { Viscosity ,135 } \\
\left(C^{\circ}\right), \text { cst }\end{array}$ & 453 & 381 & 422 & 430 & 436 & 364 & 360 & $\begin{array}{l}\text { Min } \\
350\end{array}$ & $\begin{array}{l}\text { IS } 1206 \text { (part } \\
\text { 3) }\end{array}$ \\
\hline
\end{tabular}

\section{Marshall Mix Design}

This test methodology is utilized as a part of planning and assessing DBM mixes and is widely utilized as for the paving jobs. Appropriately composed bituminous blend will withstand substantial loads due to traffic loads under antagonistic climatic conditions furthermore satisfy the prerequisite of auxiliary and asphalt surface qualities. At first the Marshall Test specimens are set up in agreement to the standard method for DBM Grade II (MoRTH-500-10), with chose total reviewing and differing bitumen substance are arranged and tried for assessing Marshall Properties. The Marshall method of mix design was employed to design the mixture for dense bituminous macadam as shown in Table 4. 
The OBC (optimum binder content) for VG-30 was $4.52 \%$ by weight of mix respectively. For each performance test three Marshall Samples were prepared and tested, and average values of the results have been reported.

Table 4: Volumetric Properties of VG 30

\begin{tabular}{|c|c|c|c|c|c|c|c|c|}
\hline $\begin{array}{l}\% \text { Bit. } \\
\text { By } \\
\text { Weight } \\
\text { of Mix }\end{array}$ & $\begin{array}{c}\text { Bulk Sp. } \\
\text { Gr. } \\
(\mathrm{Gmb})\end{array}$ & $\begin{array}{c}\text { Stability } \\
(\mathrm{KN})\end{array}$ & $\begin{array}{c}\text { Voids in } \\
\text { Mineral } \\
\text { Agg. VMA } \\
(\%)\end{array}$ & $\begin{array}{c}\text { Voids } \\
\text { Filled with } \\
\text { Bitumen } \\
\text { VFB }(\%) \\
\end{array}$ & $\begin{array}{l}\text { Flow } \\
(\mathrm{mm})\end{array}$ & $\begin{array}{c}\text { Air Voids } \\
\text { VA }(\%)\end{array}$ & Parameters & $\begin{array}{c}\text { Binder } \\
\text { Content } \\
4.52(\%)\end{array}$ \\
\hline 3.5 & 2.520 & 10.86 & 14.01 & 48.26 & 1.53 & 7.25 & $\begin{array}{c}\text { Stability } \\
(\mathrm{KN})\end{array}$ & 13.24 \\
\hline 4.0 & 2.566 & 13.03 & 12.88 & 65.42 & 2.60 & 4.45 & $\begin{array}{c}\text { Bulk Sp. } \\
\text { Gr. }\end{array}$ & 2.585 \\
\hline 4.5 & 2.580 & 13.24 & 12.88 & 70.96 & 3.07 & 3.74 & VA \% & 3.53 \\
\hline 5.0 & 2.572 & 12.19 & 13.59 & 75.21 & 4.04 & 3.37 & VFB \% & 72.18 \\
\hline 5.5 & 2.566 & 10.62 & 13.82 & 78.53 & 4.93 & 2.97 & VMA $\%$ & 12.69 \\
\hline Limits & $\ldots \ldots \ldots$ & $\operatorname{Min} 9$ & $12-15$ & $65-75$ & $2-4$ & $3-5$ & Flow & 3.07 \\
\hline
\end{tabular}

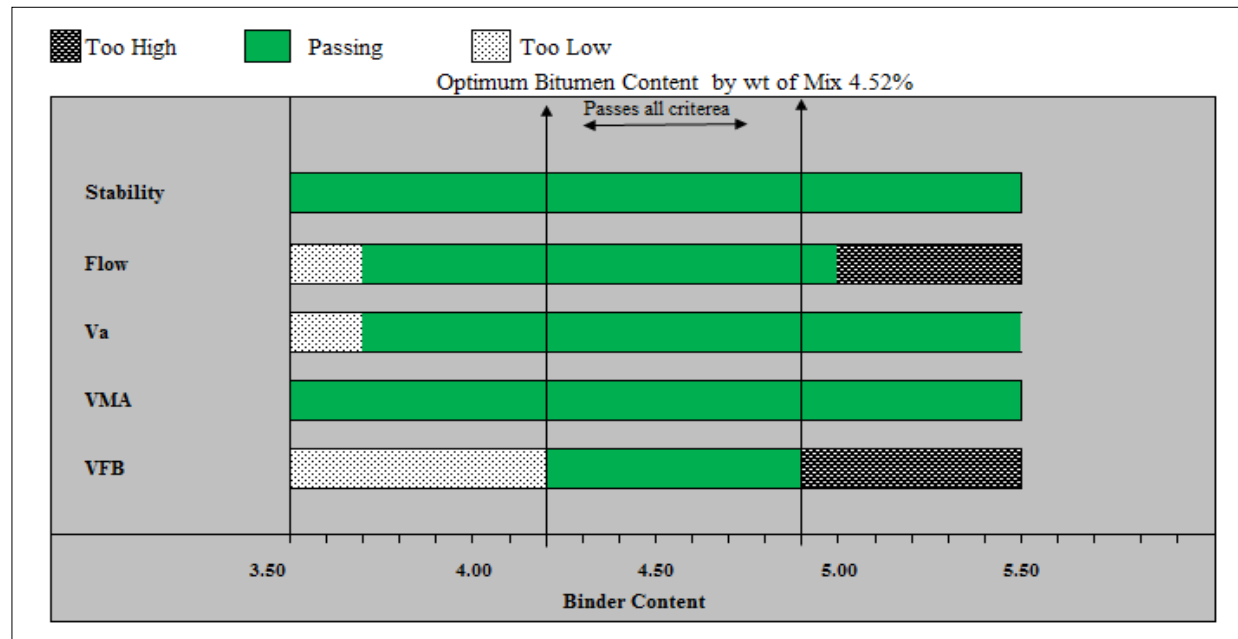

Figure 1: Narrow Range for OBC

The measurements and the temperature at which WMA samples gave comparable values as HMA were chosen as the ideal dosage of added substance and the ideal blend temperature for two sorts of fasteners. It included planning of Marshall Specimens at various dosages of an added substance and at different temperatures going from $110^{\circ} \mathrm{C}$ to $130^{\circ} \mathrm{C}$. Table 5 and 6 indicates after effects of this some portion of examination. Control tests of HMA were made at $155-160^{\circ} \mathrm{C}$ for VG30 binder. Table 7 shows the optimum additive dose and mixing temperatures of warm mix additives.

Table 5: Volumetric properties of VG 30 with Evotherm at 4.52\% OBC 


\begin{tabular}{|c|c|c|c|c|c|c|c|c|c|c|}
\hline \multicolumn{7}{|c|}{ SUMMARY OF TEST RESUL TS FOR VG 30 WITH EVOTHERM FOR DBM MIX DESIGN GRADING II } \\
\hline EVOTHERM & \multicolumn{3}{|c|}{$\begin{array}{c}0.2 \% \\
\text { Evotherm }\end{array}$} & \multicolumn{3}{c|}{$\begin{array}{c}0.4 \% \\
\text { Evotherm }\end{array}$} & \multicolumn{3}{c|}{$\begin{array}{c}0.6 \% \\
\text { Evotherm }\end{array}$} & Limits \\
\hline TEMP. ${ }^{\circ} \mathrm{C}$ & 110 & 120 & 130 & 110 & 120 & 130 & 110 & 120 & 130 & $\ldots \ldots \ldots .$. \\
\hline CDM, gm/cc & 2.55 & 2.566 & 2.549 & 2.516 & 2.532 & 2.552 & 2.559 & 2.565 & 2.563 & $\ldots \ldots \ldots$ \\
\hline Air Voids \% & 4.74 & 4.41 & 5.11 & 5.62 & 5.99 & 5.26 & 4.6 & 4.12 & 3.97 & $3-5$ \\
\hline VMA, \% & 13.73 & 13.36 & 13.93 & 15.03 & 14.51 & 13.81 & 13.6 & 13.39 & 13.45 & $12-15$ \\
\hline VFB, \% & 65.44 & 66.98 & 63.30 & 62.61 & 58.71 & 61.90 & 66.16 & 69.25 & 70.45 & $65-75$ \\
\hline Stability, KN & 10.23 & 11.83 & 10.95 & 9.86 & 11.35 & 10.12 & 11.02 & 11.77 & 11.36 & Min 9 \\
\hline Flow, mm & 2.17 & 3 & 3.33 & 2.67 & 3.2 & 2.83 & 2.83 & 3.0 & 3.17 & $2-4$ \\
\hline
\end{tabular}

Table 6: Volumetric properties of VG 30 with Sasobit at $4.52 \% \mathrm{OBC}$

\begin{tabular}{|c|c|c|c|c|c|c|c|c|c|c|}
\hline \multicolumn{9}{|c|}{ SUMMARY OF TEST RESUL TS FOR VG 30 WITH SASOBIT FOR DBM MIX DESIGN GRADING II } \\
\hline SASOBIT & \multicolumn{3}{|c|}{$\begin{array}{c}1 \% \\
\text { Sasobit }\end{array}$} & \multicolumn{3}{c|}{$\begin{array}{c}2 \% \\
\text { Sasobit }\end{array}$} & \multicolumn{3}{c|}{$\begin{array}{c}3 \% \\
\text { Sas obit }\end{array}$} & Limits \\
\hline TEMP. ${ }^{\circ} \mathrm{C}$ & 110 & 120 & 130 & 110 & 120 & 130 & 110 & 120 & 130 & $\ldots \ldots \ldots .$. \\
\hline CDM, gm/cc & 2.531 & 2.57 & 2.568 & 2.551 & 2.576 & 2.543 & 2.51 & 2.525 & 2.517 & $\ldots \ldots \ldots$ \\
\hline Air Voids \% & 4.61 & 3.27 & 3.52 & 4.95 & 4.1 & 5.41 & 5.68 & 4.27 & 3.81 & $3-5$ \\
\hline VMA, \% & 14.54 & 13.21 & 13.27 & 12.17 & 11.32 & 12.46 & 13.6 & 13.06 & 13.34 & $12-15$ \\
\hline VFB, $\%$ & 68.3 & 75.25 & 73.46 & 59.35 & 63.78 & 56.63 & 58.2 & 67.29 & 71.45 & $65-75$ \\
\hline Stability, KN & 8.52 & 9.47 & 9.28 & 8.52 & 10.21 & 9.91 & 9.23 & 11.21 & 10.07 & Min 9 \\
\hline Flow, mm & 2.17 & 3.23 & 3.5 & 2.67 & 3.3 & 3.5 & 2.23 & 3.4 & 3.77 & 2.4 \\
\hline
\end{tabular}

Table 7: Optimum additive dose and mixing temperatures

\begin{tabular}{|c|c|c|}
\hline Binder & $\begin{array}{c}\text { Dosage, } \% \text { by weight of } \\
\text { binder }\end{array}$ & Mix temperature, ${ }^{\circ} \mathrm{C}$ \\
\hline VG 30 + Evotherm (E) & 0.2 & 120 \\
VG 30 + Sasobit (S) & 3.0 & 120 \\
\hline
\end{tabular}

\section{Moisture Susceptibility Test}

The moisture susceptibility of the bituminous mixes with warm blend added substances was assessed by measuring the TSR according to ASTM: D 6931-12. The ITS of the blend is resolved prior and then afterward molding of Marshall specimens and the TSR is then ascertained as the proportion of unique quality and held quality after quickened dampness molding. The air voids in every one of these tests were kept up at $7 \pm 1 \%$. For molding of the Marshall samples, these were inundated in water bath at $60^{\circ} \mathrm{C}$ for $24 \mathrm{~h}$ and thereafter kept at $25^{\circ} \mathrm{C}$ for $2 \mathrm{~h}$.

Table 8: Dry and Wet ITS values of different Mixes at OBC of Warm mix additives

\begin{tabular}{|c|c|c|c|}
\hline Type of binder & Mix ID & $\begin{array}{c}\text { Dry ITS } \\
(\mathrm{kPa})\end{array}$ & $\begin{array}{c}\text { Wet ITS } \\
(\mathrm{kPa})\end{array}$ \\
\hline \multirow{3}{*}{ VG 30 } & VG 30 (4.52\% OBC) & 352 & 218 \\
\cline { 2 - 4 } & $0.2 \%$ Evotherm & 246 & 215 \\
\cline { 2 - 4 } & $3 \%$ Sasobit & 242 & 186 \\
\hline
\end{tabular}

\section{Tensile Strength Ratio}

The Tensile Strength Ratio (TSR) is utilized as a measure of dampness vulnerability. Figure 2 demonstrate the TSR values for all the blends. It demonstrates that the expansion of the warm blacktop added substances enhances the dampness helplessness of the blends.

The perceptions uncover that among the diverse blends arranged utilizing distinctive folios and warm blend added substances; the Evotherm demonstrates the minimum dampness weakness. At the end of the day, Evotherm indicates higher imperviousness to dampness harm soon after the asphalt 
had been laid. This demonstrates the Evotherm grants against stripping properties to the blend, and this property of the added substance is accounted for by other analyst additionally (Yu, 2012).

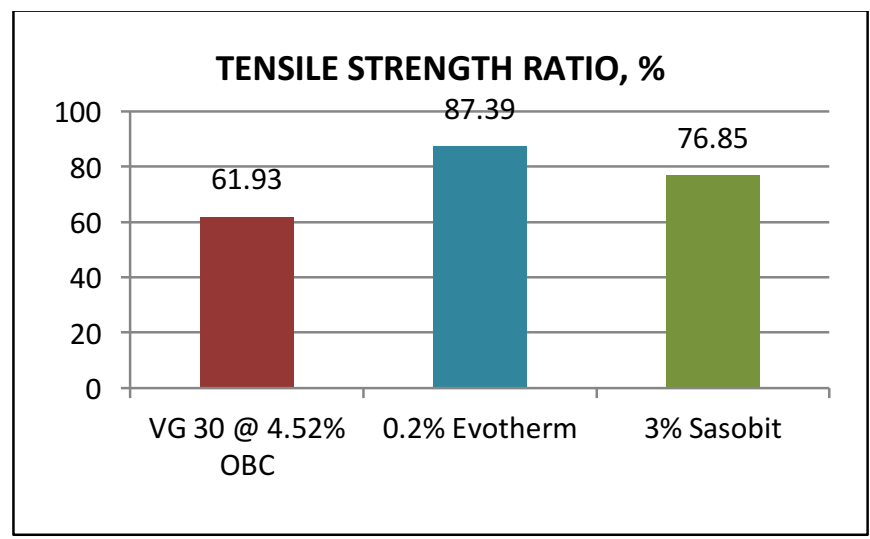

Figure 2: Tensile Strength Ratio

\section{Static Creep Test}

The static creep test was directed to appraise the rutting capability of bituminous blends under unconfined conditions. This test is led by applying a static heap of $100 \mathrm{kPa}$ to Marshall Specimens at a temperature of $40^{\circ} \mathrm{C}$ for a time of one hour and afterward measuring the lasting deformation of the sample subsequent to emptying. The test samples were put in a controlled temperature chamber for 3-4 hours before beginning of the test to convey the samples to the test temperature. The samples were at first adapted for 10 minutes with $10 \mathrm{kPa}$ static load to make up for any specimen variety.

Creep is the time subordinate distortion coming about because of a steady connected anxiety. Static creep test is utilized to decide changeless disfigurement in the asphalt. This test is additionally corresponded with the rutting capability of the blends. This test is led on marshal tests by applying 100 $\mathrm{kPa}$ static load for one hour at $40^{\circ} \mathrm{C}$ temperature then the heap is discharged. Table 9 demonstrates the watched estimations of static creep test:

Table 9: Static Creep Test for different mixtures

\begin{tabular}{|c|c|c|c|}
\hline Type of binder & $\begin{array}{c}\text { Accumulated strain } \\
\text { (microns) }\end{array}$ & $\begin{array}{c}\text { Permanent strain } \\
\text { (microns) }\end{array}$ & Recovery (\%) \\
\hline VG 30@ $4.52 \%$ OBC & 16620 & 14840 & 10.70 \\
\hline $0.2 \%$ Evotherm & 16172 & 14332 & 11.37 \\
\hline $3 \%$ Sasobit & 15570 & 13842 & 11.09 \\
\hline
\end{tabular}

Accumulated strain is the ratio of deflection at one hour to the specimen and the height of the specimen. It was observed from table 8 that warm mixes showed more resistance to permanent deformation than the control mixes. Warm asphalt mixes shows higher recovery than control mixes.

\section{Dynamic Creep Test}

It test was performed on Marshall Specimens prepared using different binders and warm mix additives. The test was performed on Universal Testing Machine at a temperature of $40^{\circ} \mathrm{C}$. Specimens were placed in the temperature control cabinet for 3-4 hours to increase the core temperature of the specimen to the test temperature. A seating stress of $11 \mathrm{kPa}$ was applied on the specimen to ensure a positive contact between the loading plate and the specimen. The test was conducted as per NCHRP 9 
- 19 (report 465). A cyclic stress of $69 \mathrm{kPa}$, having a haversine waveform with loading period of $0.1 \mathrm{~s}$ followed by a rest period of $0.9 \mathrm{~s}$, was applied during the test and total accumulated strain (\%) was recorded. The test was performed for 3600 cycles.

Table 10: Dynamic Creep Test results at $40^{\circ} \mathrm{C}$

\begin{tabular}{|c|c|}
\hline Mix ID & Total permanent strain, \% \\
\hline VG 30@ $4.52 \%$ OBC & 0.678 \\
\hline $0.2 \%$ Evotherm & 0.462 \\
\hline $3 \%$ Sasobit & 0.372 \\
\hline
\end{tabular}

The deformation resistance characteristics of bituminous mixtures were evaluated through a dynamic creep test. The total permanent strains in the different mixes at $40^{\circ} \mathrm{C}$ are given in Table 10 . The total permanent strain in a mix is an indicator of rutting and the results show low rutting in mixes with warm mix additives when compared with control mixes. Further, the control HMA mixes showed more permanent strains than WMA mixes. The freshly prepared warm mixes with both binders showed less permanent strain in comparison to control HMA mix.

\section{Conclusion}

The performance tests conducted on Marshall Specimens VG30 bituminous mix with and without warm mix additives showed that warm mixes prepared had better resistance to moisture susceptibility and permanent deformation than control hot mixes. VG30 mixes containing the warm asphalt additives had significantly higher TSR values than control mixes which indicates warm asphalt mixes showed better resistance to moisture induced damage and under static loading this would further imply that treated mixtures appeared to be capable of withstanding larger tensile stress prior to cracking, also warm asphalt mixes shows higher recovery than control mixes. Also air voids are seen within permissible limit which also indicates greater resistance to rutting, though slight change in reduction of ITS is seen. It can be clearly seen that the addition of the additives seems to have a positive effect on the strength of the samples. It can be said that the strength is inversely proportional to air voids. Evotherm demonstrates the minimum dampness weakness followed by Sasobit and Evotherm $(0.2 \%)$ satisfies the limit while other wma additives are having slightly lower limit then prescribed by code $(\geq 80)$. Also possess stronger low temperature cracking resistance property. Control HMA mixes showed more permanent accumulated strains in dynamic creep tests than WMA mixes. This shows that warm asphalt mixes will have more resistance to permanent deformation than the hot asphalt mixes.

\section{References}

Standard Codes:

1. ASTM D4402 - 06: "Standard Test Method for Viscosity Determination of Asphalt at Elevated Temperatures Using a Rotational Viscometer".

2. IS: 1202- 1978, "Methods for testing tar and bituminous materials: determination of specific gravity".

3. IS: 1203-1978, "Methods for testing tar and bituminous materials: determination of penetration".

4. IS: 1205-1978, "Methods for testing tar and bituminous materials: determination softening point".

5. IS: 1206- 1978, "Methods for testing tar and bituminous materials: determination of viscosity".

6. IS: 1202- 1978, Methods for testing tar and bituminous materials: determination of specific gravity, Density, voids, absorption and bulking.

7. IS: 1208-1978, "Methods for testing tar and bituminous materials: determination of Ductility".

8. IS: 2386 (Part 1) - 1963, "Methods of test for Aggregates for concrete: Particle size and shape".

9. IS: 2386 (Part 4) - 1963, Methods of test for Aggregates for concrete: Impact value and Abrasion value.

10. IS: 6241-1974, "Method of test for determination of stripping value of road aggregate". 
Papers:

[1.] Ahmad Kamil Arshad, Frag Ahmed Ma Kridan, Mohd Yusof Abdul Rahman, "The Effects of Sasobit ${ }^{\circledR}$ Modifier on Binder at High and Intermediate Temperatures", International Journal of Engineering and Advanced Technology (IJEAT) ISSN: 2249 8958, Volume-2, Issue-3, February 2013.

[2.] Airey GD, Mohammed MH, Fitcher C, "Rheological characteristics of synthetic road binders", Fuel, 2008, 87: 1763-75.

[3.] Ali Jamshidi, Meor Othman Hamzah, Mohamad Yusri Aman, "Effects of Sasobit ${ }^{\mathbb{R}}$ Content on the Rheological Characteristics of Unaged and Aged Asphalt Binders at High and Intermediate Temperatures", Materials Research. 2012; 15(4): 628-638.

[4.] Ambika Behl, Prof Satish Chandra, Prof V.K Aggarwal, Dr.S Gangopadhyay, "Effect of Sasobit on Viscosity and Rheology of Bituminous Binders", Indian Highway Journal.

[5.] A.M.M. Abd El Rahman , M. EL-Shafie, S.A. El Kholy, "Modification of local asphalt with epoxy resin to be used in pavement", Egyptian Journal of Petroleum (2012) 21, 139-147.

[6.] Ángel Vega-Zamanilloa, Miguel A. Calzada-Péreza, Elsa Sánchez-Alonsoa, Hernán Gonzalo-Ordenb, "Density, adhesion and stiffness of warm mix asphalts", Elsevier, Science Direct, Procedia - Social and Behavioral Sciences 160 ( 2014 ) 323 -331 .

[7.] Arshad, A.K., Sukaimy, M.F, Kamaluddin, N.A. and Daud, N.L.M., "Evaluation on Volumetric Properties and Resilient Modulus Performance of Warm Mix Asphalt (WMA)", International Sustainability and Civil Engineering Journal Vol.1, No.1, (July 2012).

[8.] Audrius Vaitkus, Donatas Čygas, Alfredas Laurinavičius, Zigmantas Perveneckas, "Analysis and Evaluation of possibilities for the use of Warm Mix Asphalt in Lithuania", The Baltic Journal of Road and Bridge Engineering, 2009, 4(2): 80-86.

[9.] Ashok Julaganti, Rajan Choudhary, Eleena Gao, "Effect on Physical Properties of Modified Binders on addition of WMA additives", International Journal Of Current Engineering And Scientific Research (IJCESR), ISSN (Print): 2393-8374, (Online): 2394-0697, Volume-1, Issue-4,2014.

[10.] Brian D Prowell, Graham C. Hurley, Everett crews (2007) "Field Performance of Warm-Mix Asphalt" Transportation Research Record Journal of the Transportation Research Board (Impact Factor: 0.44). 01/2007; 1998(1):96-102. DOI: $10.3141 / 1998-12$

[11.] Behnam Kheradmand, Ratnasamy Muniandy, Law Teik Hua, Robiah Bt. Yunus and Abbas Solouki,“An overview of the emerging warm mix asphalt technology”, International Journal of Pavement Engineering, Vol 15, No., 79-94.

[12.] Behl, Ambika, Bose, Sunil, Sharma, Girish, Kumar, Gajendra, and Devi, Uma (2011), "Warm Bituminous Mixes: The Wave of the Future?" Journal of the Indian Road Congress, July - September 2011, pp 101-107.

[13.] Benjamín Colucci, Freddie Salado, "Analysis of Warm Mix Asphalt Additives", Twelfth LACCEI Latin American and Caribbean Conference for Engineering and Technology (LACCEI'2014) "Excellence in Engineering to Enhance a Country's Productivity" July 22 - 24, 2014 Guayaquil, Ecuador.

[14.] Croteau JM, Tessier B, "Warm mix asphalt paving technologies: a road builder's perspective", Annual Conference of the transportation association of Canada, 2008.

[15.] Fabricio LV, Randy CW, "Analysis of hot mix asphalt lab compactability using lab compaction parameters and mix characteristics", J Transportation Research Board, 2008, 2057: 89-98

[16.] Hamzah MO, Jamshidi A, Shahadan Z, "Evaluation of the potential of Sasobit to reduce required heat energy and $\mathrm{CO}_{2}$ emission in the asphalt industry", Journal of Cleaner Production, 2010, 18:59-65.

[17.] Hurley, G.C.and Prowell , B.D. (2004), "Evaluation of Aspha -min (Zeolite)for use in Warm Mix Asphalt ," NCAT Report.

[18.] H.P. Bitumen Handbook, Hindustan Petroleum Corporation Limited, Mumbai, India.

[19.] Mallick,R. B., J.E. Bradley and R.L.Bradbury, Evaluation of Heated RAP material and Wax-Modified Asphalt for use in Recycled Hot-Mix Asphalt. In Transportation Research Record: Journal of Transportation Research Board, no. 1998, Transportation Research Board of the National Academies, Washington, D.C., 2007, pp 112-122.

[20.] Meadwestvaco (2003), "EVOTHERM ${ }^{\mathrm{TM}}$ warm mix asphalt-The next-generation sustainable paving solution". (www.majeskaassociates.com/images/Evotherm.pdf)

[21.] MindaugasKilas, Audrius Vaitkus ,Miglè Paliukaitė (2010) "Warm Mix Asphalts Research, Analysis and Evaluation" Modern Building, Materials, Structures and Techniques, May 19-21,2010, Vilnius, Lithuania, The $10^{\text {th }}$ International Conference.

[22.] MoRTH 2001 (Ministry of Road Transport and Highways), "Specifications for road and bridge works, $4^{\text {th }}$ revision, Indian Roads Congress, New Delhi.

[23.] Manjunath K.R, Dheeraj Kumar N, Thippeswamy G.S, "Performance and Evaluation on Marshall Stability Properties of Warm Mix Asphalt Using Evotherm and Cecabase Rt ${ }^{-A}$ Chemical Additive", International Journal of Engineering Trends and Technology (IJETT) - Volume 12 Number 8 - Jun 2014

[24.] Prowell, B.D., G.C. Hurley, and E.Crews, "Field Performance of Warm-Mix Asphalt at National Center for Asphalt Technology Test Track" Transportation Research Record: Journal of the Transportation Research Board No. 1998, Washington, D.C.,2007, pp. 96-102.

[25.] Prithvi Singh Kandhal, V. K. Sinha \& A. Veeraragavan, "A Critical Review of Bituminous Paving Mixes Used in India", Indian Highway Journal. 
[26.] Prithvi Singh Kandhal, "Warm Mix Asphalt Technologies: An Overview", Journal of the Indian Roads Congress, JulySeptember 2010

[27.] Renugadevi. A, "Evaluation of Marshall Properties of Warm Mix Asphalt using Sasobit", International Journal of Engineering Sciences \& Research Technology.

[28.] Revansiddappa M, Dr.Kiran Kumar, Manjunath. S, Arvind C, Suraj Pokalwar, "Laboratory Evaluation of HMA and WMA in BC Layer", IJSRD - International Journal for Scientific Research \& Development| Vol. 2, Issue 10, 2014 | ISSN (online): 2321-0613.

[29.] Roberts, F. L., Kandhal, P. S., Brown, E. R., Lee, D., and Kennedy, T., (1996), "Hot Mix Asphalt Materials, Mixtures, Design, and Construction" NAPA Education Foundation, Lanham, Maryland. Second Edition, pp. 241-250.

[30.] Rubio MC, Martinez G, Baena L, Moreno F, "Warm mix asphalt: an overview", Journal of Cleaner Production, 2012, 24:76-84.

[31.] Liantong Mo, Xun Li, Xing Fang, M. Huurman, Shaopeng Wu, “ Laboratory investigation of compaction characteristics and performance of warm mix asphalt containing chemical additives", Construction and Building Materials, 2012, 239247.

[32.] Xijuan Xu. (2011), "Performance of Low-Carbon Environmental Warm Mix Asphalt", American Society of Civil Engineers".

[33.] Xiao FP, Amirkhanian SN, “ Effects of liquid antistrip additives on rheology and moisture susceptibility of water bearing warm mixtures", Construction and Building Materials, 2010, 24: 1649-55.

[34.] Yu Kuang, "Evaluation of Evotherm as a WMA technology compaction and anti-strip additive" Graduate thesis and Dissertations, IOWA State University, 2012.

[35.] Zunjhang (2010) "Effects of Warm Mix Asphalt Additives on Bitumen Mixture Characteristics and Pavement performance" Civil Engineering Theses, Student Research, University of Nebraska-Lincoln. 